\title{
INTERAKSI HUKUM LOKAL DAN HUKUM NASIONAL DALAM URUSAN PERTANAHAN DI DAERAH ISTIMEWA YOGYAKARTA
}

(Interaction of Local Law and National Law in Matter of Land in Yogyakarta)

Tyas Dian Anggraeni, S.H., M.H.

Kepala Sub Bidang Penelitian Kebutuhan Hukum Bidang Substansi Hukum

Pusat Penelitian dan Pengembangan Sistem Hukum Nasional BPHN

\begin{abstract}
Abstrak
Tanah dalam konsep budaya Jawa menjadi hal yang amat sakral dan penting. Bagi masyarakat Jawa, tanah memiliki nilai yang setara dengan harga diri manusia. Seperti halnya di Daerah Istimewa Yogyakarta (DIY), tanah memiliki nilai tersendiri, termasuk juga sistem pengelolaannya. Bahkan Undang-undang Nasional tidak mampu menembus sistem pengelolaan tanah di DIY. Tulisan ini akan mengkaji lebih jauh tentang sejarah keistimewaan urusan pertanahan di Kasultanan dan Paku Alaman Yogyakarta dan realitasnya dalam menyikapi Rancangan Undang-Undang keistimewaan Yogyakarta. Dengan menggunakan metode yuridis normatif, sejarah penguasaan dan pemilikan tanah oleh raja atau Sultan Yogyakarta dan Paku Alam merupakan pelaksanaan kesepakatan dari perjanjian Giyanti yang dikukuhkan kembali dalam amanat penggabungan diri Sultan dan Paku Alam ke dalam Pemerintahan Republik Indonesia. Dengan demikian Yogyakarta mempunyai sistem pengelolaan tanah yang khusus, ada yang mengikuti hukum pertanahan nasional, dan ada pula yang masih diatur oleh Rijksblad Kasultanan dan Rijksblad Paku Alaman. Agar tidak menimbulkan masalah atau polemik baru dalam dinamika politik dan sejalan dengan sistem hukum nasional, masalah pertanahan di DIY perlu mendapat perhatian khusus.
\end{abstract}

Kata kunci: agraria, kesultanan Yogyakarta, keistimewaan daerah, politik

\section{Abstract}

Land in the concept of Javanese culture into something that is sacred and important. For the Javanese, the land has a value equivalent to human dignity. As in the Special Region of Yogyakarta (DIY), the land has value, including its management system. Even the National Law can not penetrate the soil management systems in the province. This paper will examine further features of the history of land affairs in the Sultanate of Yogyakarta and Paku Alaman and reality in the bill addressing the privilege of Yogyakarta. By using a normative juridical methods, the history of the control and ownership of land by the king or the Sultan of Yogyakarta and Paku Alam is an implementation of the agreement Giyanti agreement which reaffirmed the mandate of merging himself Sultan and Paku Alam to the Government of the Republic of Indonesia. Thus Yogyakarta has a special system of land management, there are following the national land laws, and some are still governed by the Sultanate and Rijksblad Rijksblad Paku Alaman. In order not to cause any problems or new polemical and political dynamics in line with the national legal system, problems of land in the province needs special attention.

Keywords: agrarian, land, the sultanate of Yogyakarta, the privilege, politics 


\section{A. Latar belakang}

Tanah dalam konsep dan budaya Jawa menjadi hal yang amat penting sebagaimana diungkapkan dalam pepatah "Sakdhumuk bathuk sanyari bhumi, ditohi pati, pecahing dhadha wutahing ludira". Makna dari ungkapan tersebut bahwa kedudukan tanah bagi masyarakat Jawa yang agraris nilainya setara dengan harga diri manusia yang dicerminkan dengan dahi, akan dikukuhi sampai pecahnya dada, dan tumpahnya darah. $^{1}$

Daerah Istimewa Yogyakarta (DIY) dikenal mempunyai sistem pengelolaan tanah yang khusus. Undang-Undang Pokok Agraria (UUPA) seakan tidak mampu menembus sistem pengelolaan tanah yang khusus dan mandiri tersebut. Sebagai bekas wilayah Kasultanan dan Pura Pakualaman, DIY mempunyai tiga kelompok status tanah dengan sistem hukum yang berbeda pengaturannya. Pertama, tanah bekas hak barat yang dipunyai oleh orang-orang Eropa dan Timur Asing. Tanah model ini telah dikonversi menjadi salah satu hak atas tanah menurut UUPA dan tunduk pada ketentuan hukum agraria nasional. Kedua, tanah milik Kasultanan dan Pakualaman yang telah diberikan menjadi milik perorangan atau desa. Tanah ini diatur dengan Peraturan Daerah. Ketiga, tanah milik Sultan dan Pakualam yang berada di bawah kewenangan
Kasultanan dan Pakualaman. Penguasaan dan penggunaan tanah ini diatur berdasarkan Rijksblad Kasultanan dan Pakualaman.

Terdapat lembaga di Keraton yang mengurusi tentang pertanahan yaitu lembaga Kawedanaan Ageng Purnakawan Wahono Sarto Griyo.Suatu lembaga yang ada di Keraton yang menetapkan kebijakan mengenai tanah Keraton.

Sedangkan untuk pengurusan sehari-hari atau operasionalnya tanah milik Kasultanan dan Pura Pakualaman dilakukan oleh Paniti Kismo.Paniti Kismo adalah sejumlah abdi dalem yang tergabung dalam satuan khusus, bertugas melakukan pengelolaan tanah Kasultanan dan Paku Alaman. Organisasi ini mempunyai struktur yang cukup rapi sampai di tingkat desa dan mempunyai otoritas penuh dalam pengelolaan serta pemanfaatan tanah Kasultanan dan Pura Paku Alaman untuk berbagai kepentingan dan kesejahteraan rakyat di Yogyakarta.

Hingga saat ini keberadaan tanah Kasultanan dan Pura Paku Alaman tersebut terhampar luas di berbagai daerah di Yogyakarta. Tanah-tanah tersebut dipergunakan untuk kepentingan rakyat, seperti digunakan atau ditempati sebagai rumah tinggal, gedung sekolah, perkantoran, lahan pertanian, penghijauan, tempat ibadah, dan pemakaman. Rakyat berhak menggunakan tanah tersebut, namun tidak bisa mengambil alih hak kepemilikannya. 
Dari sini dapat dilihat bahwa Sultan dan Paku Alam mempunyai hak milik penuh atas seluruh tanah Kasultanan dan Pura Paku Alaman (domein verklaring).

Rakyat yang kebetulan menempati tanah-tanah Kasultanan dan Pura Paku Alaman dibekali dengan Serat Kekancingan sebagai tanda bahwa dia mempunyai hak untuk tinggal di tanah tersebut. Kaitannya dengan pajak, berbekal Serat Kekancingan yang dikeluarkan oleh keraton tersebut, rakyat yang memanfaatkan tanah tersebut terbebas dari pungutan pajak tanah sebagaimana diatur dalam hukum agraria nasional. Bahkan rakyat pun tidak perlu menyerahkan Glondhong Pengarem-arem atau semacam uang terima kasih kepada pihak keraton karena boleh menggunakan tanah tersebut. Dengan kata lain tanah milik Kasultanan dan Pura Pakualaman tersebut digunakan secara gratis oleh rakyat Yogyakarta serta diperkenankan untuk bisa menempati tanah itu secara turun temurun. Disinilah terletak hubungan erat antara sultan dengan rakyatnya. Sultan berharap dapat berbagi rasa dengan rakyatnya melalui sistem penataan tanah yang tidak saling membebani.

Selain penggunaan tanah untuk kesejahteraan rakyatnya secara langsung, Sultan juga menerapkan prinsip larangan pengasingan tanah atau memperalihkan tanah kepada Warga Negara Indonesia (WNI) non pribumi (saat ini disebut WNI keturunan). Prinsip ini diatur dalam Rijksblad Kasultanan dan Pura Pakualaman dan telah diadopsi oleh Pemerintah Daerah dengan kebijakan yang tertuang dalam Instruksi Kepala Daerah Istimewa Yogyakarta No. K./898/I/A/75. Hingga saat ini belum ada WNI non pribumi yang diberikan hak milik atas tanah.

Seorang WNI non pribumi yang ingin membeli tanah milik rakyat, harus melalui proses administrasi yang cukup panjang. Tahapan proses yang harus dilalui dimulai dengan proses pelepasan hak atas tanah oleh rakyat. Proses ini mengakibatkan tanah tersebut kembali menjadi tanah negara yang dikuasai oleh Pemerintah Daerah. Kemudian pihak yang berkepentingan mengajukan permohonan pemberian hak kepada Kepala Daerah Istimewa Yogyakarta. Hak yang diberikan juga bukan hak milik atas tanah tersebut, namun hak yang bisa diberikan untuk WNI non pribumi adalah Hak Guna Usaha (HGU) atau Hak Guna Bangunan (HGB).

Langkah tersebut bukan merupakan tindakan diskriminasi namun lebih kepada perlindungan terhadap rakyat, terutama rakyat kecil yang hidup sebagai petani. Pertimbangan atas tindakan tersebut dikarenakan WNI non pribumi biasanya mempunyai tingkat kehidupan ekonomi yang lebih tinggi dari pada golongan pribumi.

Pertimbangan lain adalah mengingat wilayah Yogyakarta yang sempit. Pemberian hakmilik bagiWNI non pribumi, dikhawatirkan akan menyebabkan rakyat kecil menjadi terdesak. Bahkan dikhawatirkan rakyat ini nantinya hanya menjadi kaum buruh di tanah mereka sendiri. Kebijakan yang dilakukan 
tersebut merupakan bagian dari budaya luhur "Tahta untuk Rakyat" yang sangat dijaga oleh Sultan. Tanah lahirkan tahta, tahta untuk rakyat, dimana rajanya bercermin di kalbu rakyat. Demikianlah singgasana bermartabat berdiri kokoh untuk mengayomi rakyat. ${ }^{2}$

Budaya adiluhur yang mengedepankan kesejahteraan rakyat tersebut wajib dilestarikan. Namun tidak dapat dipungkiri bahwa budaya tersebut seakan bertentangan dengan prinsip hukum nasional, yaitu UUPA dan Undang-Undang Kewarganegaraan. Banyakkalangan terutamajajaran pemerintah pusat berharap bahwa, budaya adiluhur tersebut dapat dirasionalisasikan sesuai dengan nilai-nilai modernitas dan berjiwa nasionalis. Dengan dasar nasionalisme saat ini keistimewaan DIY diusulkan untuk diatur dalam suatu undang-undang.

Diskusi yang berkembang dalam pembicaraan konsep keistimewaan Yogyakarta, terdapat tiga hal penting yang mengisi keistimewaan Yogyakarta, yaitu:

1. bidang pemerintahan;

2. bidang pertanahan,

3. bidang kebudayaan.

Khusus mengenai urusan pertanahan, hingga akhir tahun 2011 masih masuk dalam daftar inventaris masalah (DIM) yang belum disepakati pembahasannya, berdasarkan draf Rancangan Undang-Undang tentang Keistimewaan Provinsi Daerah Istimewa
Yogyakarta (RUU Keistimewaan DIY) yang diusulkan oleh pemerintah.

Terdapat beberapa pasal yang terkait dengan masalah pertanahan dalam RUU ini. Pertama, Pasal 26 yang secara utuh mengatur mengenai pertanahan. Kemudian Pasal 7, Pasal 35 dan Pasal 37.

Mengenai kewenangan urusan di bidang pertanahan dalam draf RUU Keistimewaan DIY yang diajukan oleh pemerintah, diatur dalam Pasal 7 ayat (2) d

\footnotetext{
"Kewenangan dalam urusan istimewa sebagaimana dimaksud pada ayat (1) mencakup pertanahan dan penataan ruang"
}

Sedangkan dalam penjelasan Pasal itu disebutkan bahwa kewenangan dalam urusan pertanahan dan penataan ruang meliputi kewenangan untuk mengatur dan mengurus kepemilikan, penguasaan dan pengelolaan Sultanaat Grond dan Pakualamanaat Grond. Khusus di bidang pertanahan, Sultan dan Pakualam sebagai Gubernur Utama dan Wakil Gubernur Utama berwenang memberikan arahan umum kebijakan, pertimbangan, persetujuan dan veto terhadap Rancangan Peraturan Daerah yang diajukan DPRD dan Gubernur dan/ atau Peraturan Daerah yang berlaku yang mengatur masalah pertanahan.

Pola yang diusung dalam draf RUU Keistimewaan DIY menempatkan Sultan dan Paku Alam sebagai Gubernur Utama dan Wakil 


\section{$\mathrm{R}^{\text {juknal }}$ ECHSVINDING}

Gubernur Utama yang mempunyai fungsi sebagai simbol, pelindung, penjaga budaya, pengayom dan pemersatu masyarakat. Sedangkan dalam hal penyelenggaraan pemerintahan dilaksanakan oleh Gubernur, selaku Kepala Daerah. Hal tersebut tentunya akan menimbulkan pertanyaan, ketika nantinya Kepala Daerah (Gubernur) dan Wakil Kepala Daerah (Wakil Gubernur) bukan Sultan atau Paku Alam yang sedang jumeneng atau bertahta, dimanakah letak keistimewaan Yogyakarta.

Sebab salah satu keistimewaan Yogyakarta adalah kepala daerahnya yang dipimpin oleh Sultan yang sedang Jumeneng atau bertahta saat itu dalam rangka menjaga norma-norma dasar yang diwariskan secara turun temurun.

Menyikapi kekhawatiran tersebut pemerintah pusat memberikan semacam hak veto sebagaimana diatur dalam draf Penjelasan Pasal 7 RUU Keistimewaan DIY bagi Sultan ataupun Paku Alam. Apabila melihat dalam Kamus Besar Bahasa Indonesia (online) $)^{3}$, kata veto merupakan kata benda yang mempunyai arti hak konstitusional penguasa atau pemegang pemerintahan untuk mencegah, menyatakan, menolak, atau membatalkan keputusan. Hak veto biasanya melekat pada salah satu lembaga tinggi negara merupakan suara tunggal istimewa untuk dalam pengambilan keputusan yang memiliki efek menghambat atau meniadakan keputusan mayoritas.
Dalam hubungannya dengan urusan pertanahan, berdasarkan uraian diatas dapat dilihat bahwa hak veto yang diberikan kepada Sultan dan Paku Alam terutama dalam urusan pertanahan di Yogyakarta lebih kepada persetujuan atau penolakan saja terhadap rancangan Peraturan Daerah Istimewa yang diajukan DPRD dan Gubernur dan/atau Peraturan Daerah yang berlaku dan bukan merupakan hak mengatur dan semacam hak memiliki atas tanah. Sultan dan Paku Alam tidak memiliki hak tunggal yang kuat dalam pengaturan peruntukan tanah seperti sebelumnya. Akan terjadi banyak perubahan terutama terkait masalah pertanahan di Yogyakarta ketika nantinya RUU Keistimewaan DIY menjadi undangundang. Hal inilah yang akan dibahas dalam penulisan ini.

\section{Permasalahan}

Dari uraian di atas, dirumuskan permasalahan sebagai berikut:

1. Bagaimana sejarah keistimewaan urusan pertanahan di Kasultanan dan Paku Alaman Yogyakarta?

2. Bagaimana urusan pertanahan di Yogyakarta dalam menyikapi RUU Keistimewaan DIY?

http://pusatbahasa.kemdiknas.go.id/kbbi/, diakses tanggal 5 Januari 2012. 


\section{Metode Penelitian}

Penulisan ini didasarkan pada penelitian hukum normatif. ${ }^{4}$ Data yang digunakan adalah data sekunder yang diperoleh dari buku kepustakaan, artikel, serta peraturan perundangan yang berkaitan dengan masalah pertanahan di Yogyakarta.

\section{E. Pembahasan}

\section{Sejarah Keistimewaan Urusan Pertanahan di Kasultanan dan Paku Alaman Yogyakarta}

Sejarah penguasaan dan pemilikan tanah oleh raja atau Sultan Yogyakarta dan Paku Alam merupakan pelaksanaan kesepakatan dari perjanjian Giyanti. Perjanjian yang dilaksanakan di daerah Giyanti pada tanggal 13 Februari 1755 membagi Kerajaan Mataram menjadi dua, yaitu Kasunanan Surakarta (Susuhunan) dan Kasultanan Ngayogyakarta Hadiningrat (Kasultanan). ${ }^{5}$ Pada masa kekuasaan Inggris, oleh Letnan Gubernur Thomas Stamford Raffles, wilayah Kasultanan Yogyakarta disempitkan lagi pada tahun 1813 menjadi wilayah Kasultanan dan wilayah Pakualaman. ${ }^{6}$ Hasil perjanjian Giyanti menyatakan bahwa Sultan Hamengku Buwono mempunyai hak milik (domein) atas tanah di wilayah barat Kerajaan Mataram dan hal ini tetap harus hidup dalam kesadaran hukum masyarakat. ${ }^{7}$ Konsekuensi dari diberlakukannya asas domein tersebut maka rakyat tidak mempunyai hak eigendom. Penguasaan tanah oleh rakyat melalui hak anggaduh (menggarap) dengan kewajiban menyerahkan separo atau sepertiga hasil tanahnya jika merupakan tanah pertanian dan apabila berupa tanah pekarangan, maka mereka dibebani kerja tanpa upah untuk kepentingan Raja. ${ }^{8}$

Berdasarkan kewenangannya sebagai pemilik dan penguasa tanah mutlak atau pemegang domein. Sultan telah menentukan atau menetapkan hak-hak atas tanah yang dapat dimiliki oleh rakyatnya, yaitu meliputi:

a. Hak anggaduh;

b. Hak angganggo (memakai) turuntemurun;

c. Hak andarbeni (memiliki);

d. Hak pungut hasil;

e. Hak didahulukan;

f. Hak blengket.

Soerjono Soekanto dan Sri Mamudji, Penelitian Hukum Normatif, Suatu Tinjauan Singkat, (Jakarta: Raja Grafindo Persada, 2003), hal. 14.

Moedjanto, G., Kasultanan Yogyakarta dan Kadipaten Pakualaman, (Yogyakarta: Kanisius, 1994), hal.13.

Selo Soemardjan, Perubahan Sosial di Yogyakarta, (Yogyakarta: Gadjah Mada University Press, 1981), hal. 18. KPH Notoyudo dalam Umar Kusumoharyono, Eksistensi Tanah Kasultanan (Sultan Ground) Yogyakarta setelah berlakunya UU No. 5 / 1960, Yustisia Edisi Nomor 68, Mei - Agustus 2006, hal. 2.

8 Boedi Harsono, Undang - Undang Pokok Agraria, Sejarah Penyusunan Isi dan Pelaksanaannya, (Djakarta: Djambatan, 1968), hal. 56. 
Pengaturan tersebut berlaku di seluruh wilayah Kasultanan Yogyakarta. Asas domeinverklaring tersebut ini merupakan pernyataan sepihak dari Sultan. Seperti yang termuat dalam Pasal 1 Rijksblaad Kasultanan No. 16 tahun 1918:

"Sakabehing bumi kang ora ana tandha yektine kadarben ing liyan, mawa wenang eigendom, dadi bumi kagungane Kraton Ingsun Ngayogyakarta. "

(Seluruh tanah yang tidak ada tanda bukti yang dimiliki seperti eigendom menjadi milik keraton Yogyakarta).

Pernyataan yang terkesan mengedepankan feodalisme tersebut menggelitik untuk memunculkan pertanyaan apakah perbuatan tersebut bukan merupakan tindakan sewenang-wenang. Berangkat dari pemahaman pada masa tersebut, rakyat percaya bahwa sultan atau raja adalah seorang suci. Rakyat merasa bangga jika miliknya diperlukan oleh raja, pemimpin mereka yang suci. ${ }^{9} \mathrm{Hal}$ tersebut berlaku juga dalam sejarah Kasultanan Yogyakarta.

Terdapat beberapa perbuatan raja yang pada masa sekarang ini menurut kita merupakan tindakan sewenang-wenang. Namun selama tekanan tersebut tidak berat bagi rakyat perbuatan tersebut menjadi suatu hukum adat. Kekuasaan raja tidak hanya mempengaruhihakulayatpersekutuan, tetapi juga perorangan, sehingga hak milik berubah menjadi hak mengelola tanah atau hak memungut hasil saja. Kekuasaan menguatkan paham milik raja (vorstendomein) dan hak milik raja (vorsteneigendomsrecht) karena menurut adat raja adalah segala-galanya. Semuanya adalah untuk raja dan kepunyaan raja.

Dalam pelaksanaannya pemahaman tersebut hanya ditujukan untuk menghormati dan menjunjung raja mereka. Sebab dalam kenyataannya rakyat tetap menganggap dirinya sebagai pemilik hak atas tanah mereka, hal itu terbukti dengan terus berlangsungnya kegiatan seperti jual beli, sewa menyewa, gadai dan sebagainya yang dilakukan oleh rakyat di tanah mereka. Raja pun tidak menganggap dirinya sebagai pemilik tanah dalam arti yang luas. Yang diminta dari rakyat hanyalah penyetoran sebagian dari hasil bumi atas tanah mereka dan raja hanya mengatur segala urusan pertanahan di wilayahnya. ${ }^{10}$

Terdapat beberapa pembabakan pengaturan pertanahan di Yogyakarta, menurut kronologi sejarah yang intinya adalah sebagai berikut ${ }^{11}$ :

Periode pertama, berlangsung hingga tahun 1918, yakni saat dimulainya reorganisasi

9 B. Ter Haar, Asas-asas Dan Susunan Hukum Adat, Terjemahan oleh K. ng. Soebakti Poesponot, (Jakarta: Pradnya Paramita, 1985), hal. 78.

10 Erman Rajagukguk, Pemahaman Rakyat tentang Hak atas Tanah, Prisma, Jakarta, 1979, hal. 4.

11 http://triwidodowutomo.blogspot.com/2010/05/hukum-pertanahan-di-yogyakarta-sebelum.html. diakses tanggal 4 Februari 2011. 
keagrariaan. Pada masa kabekelan/apanage ini berlaku asas bahwa tanah adalah milik raja; sebagian diantaranya diberikan kepada kerabat dan pejabat keraton sebagai tanah lungguh, sedang rakyat hanya mempunyai wewenang anggadhuh (meminjam).

Dalam hal ini rakyat tidak memiliki hak hukum atas sebidang tanah, tetapi hanya sekedar menggarapnya. Oleh karenanya zaman ini merupakan zaman penderitaan bagi rakyat kecil, dimana selain diharuskan menyerahkan sebagian hasil tanamnya, rakyat masih diwajibkan bekerja di perusahaan-perusahaan pertanian.

Periode kedua, ditandai dengan dilaksanakannya perubahan dalam sistem pemilikan tanah tahun 1918 hingga tahun 1950-an. Pada masa ini raja melepaskan hak-haknya atas sebagian terbesar dari tanah yang termasuk wilayahnya, yang kemudian menjadi hak milik pribumi anggota masyarakat desa, dan diadakannya pembagian baru dari persilpersil tanah untuk penduduk desa. ${ }^{12}$

Peraturan perundang-undangan yang mengatur tentang proses perubahan sistem pemilikan tanah ini adalah Rijksblad Kasultanan 1918 No. 16 tanggal 8 Agustus 1918, yang beberapa pasalnya berbunyi sebagai berikut:

12 Ibid.
Pasal 3

(1) Sakabehe bumi kang wus kapranata maneh kang wus terang dienggo uwong cilik dienggoni utawa diolah ajeg utawa nganggo bera pangolahe, kadidene kang kasebut ing register kelurahan, iku padha diparingake marang kalurahan anyar mawa wewenang panggadhuh cara Jawa, dene bumi kang diparingake marang siji-sijine kalurahan mau, bumi kang kalebu ing wewengkone kalurahan miturut register kalurahan.

(Semua tanah yang terletak dalam wilayah yang telah diorganisir yang nyata-nyata dipakai rakyat, baik yang ditempati maupun yang diolah secara tetap atau tidak tetap sebagaimana tercatat dalam register kalurahan, diberikan kepada kalurahan baru tersebut dengan hak anggadhuh / inlandsbezitsrecht. Ada pun tanah yang diberikan kepada masing-masing kalurahan itu adalah tanah yang termasuk dalam register kalurahan).

Pasal 4

Kejaba wewenange penggadhuh tumrap bumi lungguhe lurah sarta perabot kelurahan tuwin bumi kang diparingake minangka dadi pensiune (pengarem-arem) para bekel kang dilereni, iku wenang penggadhuh kang kasebut ing bab 3 diparingake marang kalurahan mawa anglestareake wewenange kang padha nganggo bumi ing nalika tumindake pembangune pranatan anyar, wewenange nganggo bumi kang dienggo nalika iku, ditetepake

turun temurun, sarta siji-sijine kalurahan sepira kang dadi wajibe dhewe-dhewe, dipasrahi amranata dhewe ngatase angliyaake bumi sajerone sawetara lawase sarta angliyerake wewenange nganggo bumi mau, semono iku mawa angelingi pepacak kang wis utawa kang bakal ingsun dhawuhake, utawa kang panin-dake terang dhawuhingsung. 
(Kecuali hak anggadhuh atas tanah lungguh lurah dan perabot kelurahan serta tanah yang diberikan sebagai tanah pensiun para bekel (pamong desa) yang diberhentikan, hak anggadhuh / inlandsbezitsrecht yang tersebut pada pasal 3 diberikan kepada kelurahan dengan melestarikan hak para pemakai tanah pada saat berlakunya reorganisasi, hak pakai itu ditetapkan turun temurun (erfelijk gebruiksrecht), dan kelurahan diserahi mengatur sendiri mengenai 'angliyaake' tanah untuk sementara waktu (tijdelijke voorveending) dan 'angliyer-ake' hak pakai tanah (overdracht van dat gebruiksrecht), dengan mengingat peraturan yang sudah atau akan ditetapkan kemudian.

\section{Pasal 5}

(1) ingsamangsa-mangsaingsungkenamundhut kondur bumi sawatara bageyan kang padha diparingake marang kalurahan mawa wewenang penggadhuh, menawa bumi mau bakal diparingake marang kabudidayan tetanen iku bakal ingsun paringi wewenang ing atase bumi mau miturut pranatan bab pamajege bumi, mungguh laku-lakune kang kasebut ing ndhuwur iki bakal kapranatan kamot ing pranatan.

(Sewaktu-waktu hak anggadhuh / inlandsbezitsrecht yang diberikan kepada kalurahan dapat ditarik kembali jika tanah itu diperlukan untuk perusahaan pertanian / landbouw onderneming menurut aturan penyewaan tanah/grondhuur reglement).

\section{Pasal 6}

Kejaba tumrap lelakon kang kasebut ing bab 5, ingsun ora bakal mundhut bumikang dianggo uwong cilik kang katemtoake ing bab 3, menawa ora tumrap kaperluane ngakeh, semono iku mawa amaringi karugian kang tinam-toake dening Pepatihingsun, sabiyantu kalayan Kanjeng Tuan Residen ing Ngayogyakarta, sawuse karembug dening kumisi juru taksir, dene panindake kang bakal tinamtoake ing tembe kamot ing layange undang-undang Pepatihingsun.
(Selain untuk keperluan dimaksud pasal 5, Pemerintah tidak akan menarik kembali tanahtanah yang dipergunakan oleh penduduk, apabila tidak untuk kepentingan umum dan dengan ganti rugi yang ditetapkan oleh Patih Kerajaan dengan persetujuan Residen di Yogyakarta dan telah mendengar pendapat komisi taksir. Pelaksanaan hal ini akan diatur kemudian dengan peraturan Patih Kerajaan).

Mengenai proses perubahan pertanahan di wilayah Paku Alaman diatur dalam Rijksblad Paku Alaman 1918 No. 18 tanggal 17 Agustus 1918 yang isinya sama atau hampir sama dengan ketentuan diatas.

Periode akhir periode kedua ini tidak bisa dipastikan waktunya, disebabkan karena sekitar tahun 1950-an terjadi banyak peristiwa penting yang berkaitan dengan bidang agraria seperti dihapuskannya pajak kepala tahun 1946, digantikannya pajak tanah dengan pajak pendapatan tahun 1951, dan diberikannya hak milik perseorangan turun-temurun tahun 1954.

Periode ketiga, berlangsung sejak tahun 1950-an, hingga tahun 1984 yakni saat diberlakukannya Undang-Undang No. 5 Tahun 1960 secara penuh di Daerah Istimewa Yogyakarta. Pada periode ini berlaku ketentuan bahwa semua tanah yang tidak dapat dibuktikan secara hak oleh pihak lain adalah domain Keraton Yogyakarta dan Puro Pakualaman. Keraton memberikan hak anggadoh ke kelurahan. Keraton memberikan hak anggadoh turun temurun kepada rakyat yang nyata-nyata dipergunakan rakyat dan 
mulai saat ini muncul Buku Administrasi Tanah di tiap-tiap kelurahan. ${ }^{13}$

Pada periode ini, urusan pertanahan merupakan urusan rumah tangga Daerah Istimewa Yogyakarta. Daerah Istimewa Yogyakarta memberi hak milik turun temurun atas bidang tanah pada Warga Negara Indonesia. Tanda sah hak milik tanah di Yogyakarta, diluar tanah sultan adalah model D, E, dan daftar atau register leter $C$. Sedangkan tanah sah hak milik di Yogyakarta yang berada di dalam wilayah sultan adalah petikan register bawenang andarbabumi miras layang kurat petikan soko yatno pustoko.

Dalam penggunaan tanah milik keraton, Sultan (Hamengkubuwono IX) pernah menyatakan bahwa siapa saja baik perorangan maupun badan hukum dapat memanfaatkan dan menggunakan tanah keraton tersebut asalkan jelas peruntukannya dan melaporkan ke lembaga yang berwenang menangani. Sebab bagi Sultan yang penting adalah adanya pengakuan bahwa tanah tersebut adalah tanah Keraton.

Sedangkan penggunaan tanah Sultan Ground dan Pakualaman Ground dapat digolongkan menjadi ${ }^{14}$ :

Satu, tanah Keraton yang sudah diberikan kepada para sentono dengan kekacingan (sertifikat/surat yang dikeluarkan Keraton), jadi para sentono ini termasuk kerabat.

Kedua, tanah Keraton yang digunakan untuk keperluan eksistensi Keraton yaitu mungkin Keprabon yang di dalam Rancangan Undang-Undang sudah ada defenisinya.

Ketiga, tanah Keraton yang dipakai sebagai rumah jabatan

Keempat, tanah Keraton yang dipakai oleh pihak lain yaitu instansi pemerintah atau lembaga badan hukum swasta maupun perorangan, baik dengan perjanjian maupun hanya ijin saja.

Jadi selama ini eksistingnya apabila misalnya kalau pihak ketiga itu mengadakan keinginan untuk itu biasanya dari pihak Keraton maupun Pakualaman ada kerja sama dengan bupati daerah setempat, dan secara operasional bupati ini yang akan mengatur dengan pihak ketiga. Tetapi ada juga yang langsung yaitu dengan perjanjian. Kalau dengan masyarakat yaitu hanya ijin saja, yaitu dengan cara magersari.

Kelima, tanah Keraton yang masih digarap oleh masyarakat, tidak ada bangunan, baik dengan ijin maupun tidak. Termasuk yang di Pasir Besi yang di arah Kulon Progo ini dengan tanah Paku Alam Ground, kemudian kalau di Yogya umumnya, selain di Kulon Progo tersebar adalah Sultan Ground.

Risalah Rapat Panitia Kerja Komisi II DPR RI, Tentang Rancangan Undang-Undang Tentang Keistimewaan Propinsi Daerah Istimewa Yogyakarta, Senin,10 Oktober 2011, hal. 3

14 Ibid. hal. 6 
Keenam, tanah-tanah keraton yang masih kosong sama sekali dan belum dikuasai oleh pihak lain.

Sedangkan berdasarkan kedudukan tanah dan fungsinya masing-masing yakni dapat dibagi menjadi ${ }^{15}$ :

I. Tanah yang dipakai Sultan Sendiri;

II. Tanah yang diberikan Sultan kepada Pemerintah Hindia Belanda untuk kantor, gedung;

III. Tanah yang diberikan kepada orang asing (WNA): hak Eigendom, Opstal;

IV. Tanah Golongan diberikan menurut golongan abdi dalem;

V. Tanah Kasentanan diberikan kepada keluarga/ kerabat Raja;

VI. Tanah pekarangan Bupati, untuk pegawai dengan perkampungan di sekelilingnya;

VII. Tanah Kebonan dan pekarangan di luar pusat pemerintahan diberikan ke Patih (Rijkbestuurder);

VIII. Pekarangan penduduk di luar tanahtanah I-VII;

IX. Sawah Mahosan yang dikerjakan dan dipelihara Bekel dengan membayar pajak (Pajeg/Paos);

Kembali kepada kekuasaan Sultan, selain mempunyai hak milik atas tanah di wilayahnya secara utuh pada masa tersebut, terdapat prinsip lain yang unik dalam urusan pertanahan Kasultanan Yogyakarta dan Pura
Pakulaman untuk kepemilikan tanah bagi WNI non pribumi yang masih berlaku hingga sekarang. Berdasarkan Rijksblad Kasultanan 1918 nomor 16 juncto 1925 nomor 23, serta Rijksblad Paku Alaman 1918 nomor 18 juncto 1925 nomor 25, Pasal 6 ayat (1) :

"adol utawa angliyerake wewenang andarbeni utawa nganggo bumi ... marang wong kang dudu bangsa Jawa lan maneh nyewaake utawa nggaduhake bumi gawe marang wong kang dudu bangsa Jawa, ... kalarangan".

(Menjual atau memindahkan hak milik atau hak pakai atas tanah ... kepada yang bukan bangsa Jawa (baca: bangsa Indonesia) dan juga menyewakan atau menggaduhkan tanah kepada bukan bangsa Jawa (baca: bangsa Indonesia) ... dilarang).

Hak milik atas tanah tidak diberikan kepada warga negara Indonesia non-pribumi dengan pertimbangan melindungi warga pribumi yang secara ekonomis tergolong lemah.

Dapat dirasakan disini bahwa Sultan Yogyakarta sangat peduli dan selalu mengutamakan keberpihakan terhadap nasib rakyatnya. Bagi Sultan, rakyat merupakan bagian yang secara langsung mengokohkan legitimasi politik kepemimpinannya sebagaimana prinsip manunggaling kawula gusti (bersatunya rakyat dan raja). Kebijakan Sutan dalam Rijksblad yang telah diadopsi menjadi Peraturan Kepala Daerah Istimewa Yogyakarta tersebut sebenarnya telah sesuai dan selaras

15 Mochammad Tauchid., Masalah Agraria Sebagai Masalah Penghidupan dan Kemakmuran Rakyat Indonesia, Bagian Pertama, (Djakarta: Tjakrawala, 1952), hal. 135. 
dengan UUPA yang juga mempunyai misi untuk melindungi golongan masyarakat yang lemah. ${ }^{16}$ Prinsip dan kebijakan yang seakan mengandung ketidakadilan dan diskriminasi tersebut dapat diterima. Dalam hukum, suatu pandangan bahwa ketidakadilan dan diskriminasi dalam kebijakan dan perlakuan yang dimaksudkan untuk melindungi kepentingan yang lemah dapat dibenarkan dan kemudian dikokohkan dalam istilah "diskriminasi positif (positive discrimination) atau keadilan korektif (corrective justice). ${ }^{17}$

Masih berlangsungnya pengaturan oleh Sultan dan Pakualam menimbulkan kesan adanya dualisme hukum pertanahan di Yogyakarta. Namun hal tersebut merupakan konsekuensi dari keistimewaan yang dimiliki oleh Yogyakarta dibandingkan dengan daerah lain di Indonesia.

Keistimewaan yang dimiliki oleh Yogyakarta berawal dari keluarnya Amanat Sri Paduka Sultan Hamengku Buwono IX dan Sri Paduka Paku Alam VIII pada tanggal 5 September 1945 yang menyatakan bahwa Kasultanan Ngayogyakarta Hadiningrat dan Kadipaten Pakualaman adalah daerah istimewa dan merupakan bagian dari wilayah Republik Indonesia.

Sultan Yogyakarta tetap dalam kedudukannya sebagai kepala pemerintahaan yang mengendalikan semua wilayah kekuasaan kesultanan. Keistimewaan yang dimiliki oleh Sultan tidak terbatas pada status kepala daerah, melainkan juga pemerintahan, pertanahan, pendidikan, kebudayaan, anggaran keistimewaan dan posisi keraton.

Dalam amanat Penggabungan diri tersebut Sultan dan Paku Alam menyertakan kewenangan untuk menangani segala urusan pemerintahan di daerahnya. Hak tersebut antara lain untuk mengatur pemerintahannya yang meliputi penentuan sendiri cara pengangkatan dan pemberhentian pimpinan daerahnya termasuk juga mengatur urusan pertanahannya. Berdasarkan keistimewaan tersebut, saat ini di Yogyakarta terdapat beberapa kelompok status tanah dengan sistem hukum yang berbeda pengaturannya antara lain:

a. Tanah bekas hak barat yang di miliki oleh orang-orang Eropa dan Timur asing yang pada tahun 1960 yang sudah di konversi menjadi salah satu hak atas tanah menurut UUPA dan tunduk pada ketentuan hukum agraria nasional.

b. Tanah milik (domein) Kasultanan dan Pakualaman yang sudah diberikan menjadi milik perorangan dan desa sejak tahun 1954 tunduk pada ketentuan dalam beberapa Peraturan Daerah.

c. Tanah-tanah milik (domein) Sultan dan Paku Alam yang berada di bawah kewenangan Kasultanandan pakualaman yang penguasaan dan penggunaannya diatur berdasarkan Rijksblad Kasultanan dan Pakualaman.

16 Tri Widodo Utomo, Hukum Pertanahan Dalam Perspektif Otonomi Daerah, (Yogyakarta: Navila, 1992 ), hal. 120.

17 Maria Sumardjono SW, Kebijakan Pertanahan Antara Regulasi dan Implementasi , Kompas , Jakarta, 2001. 


\section{$\mathrm{R}^{\text {juknal }}$ ECHSVINDING}

Perbedaan pengaturan yang menimbulkan dualisme hukum tersebut menimbulkan ketidakpastian hukum. Ketika berbicara dalam konteks Negara Kesatuan Republik Indonesia tentunya merupakan persoalan yang serius dan harus segera diselesaikan, ketika status keistimewaan suatu daerah dapat mengalahkan hukum nasional yang berlaku. Hal ini juga tidak bisa sepenuhnya dianggap mengabaikan keberadaan keraton Yogyakarta, sebab kepastian hukum terutama dalam hal pertanahan selaras juga dengan sikap nasionalisme Sultan HB IX ketika menyatakan untuk bergabung dengan NKRI. Sultan HB IX pada saat itu sangat mengharapkan bahwa terjadinya penggabungan Keraton Yogyakarta dengan Republik Indonesia yang masih sangat muda tersebut diharapkan akan memperkokoh Negara Kesatuan Republik Indonesia sebagai satu kesatuan yang utuh.

Dalam rangka pembangunan hukum, yang merupakan proses mengakomodasi dan merespon terhadap dua dunia yaitu dunia cita-cita atau ide dan dunia nyata, jika hukum yang dibangun diharapkan daya jangkau berlaku ke masa yang akan datang tetapi dengan tidak mengabaikan kondisikondisi yang ada pada saat sekarang. ${ }^{18}$ Maka faktor sejarah dan realita dalam kehidupan masyarakat saat ini kini akan menjadi bahan untuk menyusun peraturan perundangundangan di masa mendatang.

Berdasarkan latar belakang tersebut regulasi berupa undang-undang yang secara tegas mengatur aspek-aspek keistimewaan Yogyakarta sangat diperlukan. Undang-Undang tersebut pada satu sisi harus mempertimbangkan keistimewaan Yogyakarta yang sudah diakui sejak tahun 1950. Dan pada sisi yang lain, harus dapat menyesuaikan dengan perkembangan masyarakat yang ada. Kehadiran undang-undang tersebut juga diharapkan akan mampu menciptakan kepastian hukum terutama dalam hal urusan pertanahan sehingga akan sangat berguna bagi Yogyakarta dalam menyelenggarakan proses pemerintahannya dari masa ke masa.

\section{Realitas urusan pertanahan dalam menyikapi RUU Keistimewaan DIY}

Sebagaimana telah diuraikan di atas bahwa Sultan dan Paku Alam mempunyai kewenangan mutlak terhadap urusan pertanahan di wilayahnya. Dalam RUU Keistimewaan DIY, Kewenangan urusan pertanahan diatur pada Bab IV tentang Kewenangan, dalam Pasal 7 :

1) Kewenangan Provinsi Daerah Istimewa Yogyakarta sebagai daerah otonom mencakup kewenangan dalam

18 Sacipto Rahardjo, Ilmu Hukum, (Bandung: Alumni, 1982), hal.13. 
urusan-urusan pemerintahan Provinsi sebagaimana dimaksud dalam UndangUndang tentang Pemerintahan Daerah dan urusan-urusan istimewa yang ditetapkan dalam Undang-Undang ini.

2) Kewenangan dalam urusan istimewa sebagaimana dimaksud pada ayat (1) mencakup:
a. penetapan fungsi, tugas dan wewenang Gubernur Utama dan Wakil Gubernur Utama;
b. penetapankelembagaan Pemerintah Daerah Provinsi;
c. kebudayaan; dan
d. pertanahan dan penataan ruang.

3) Penyelenggaraan kewenangan dalam urusan-urusan istimewa sebagaimana dimaksud pada ayat (2) didasarkan pada nilai-nilai kearifan lokal dan keberpihakan kepada rakyat.

4) Pengaturan lebih lanjut kewenangan dalam urusan-urusan istimewa sebagaimana dimaksud pada ayat (2) dan ayat (3) diatur dengan Perdais.

Dalam penjelasan Pasal itu disebutkan bahwa:

"Kewenangan dalam urusan pertanahan dan penataan ruang meliputi kewenangan untuk mengatur dan mengurus kepemilikan, penguasaan dan pengelolaan Sultanaat Grond dan Pakualamanaat Grond. Khusus di bidang pertanahan, Sultan dan Pakualam sebagai Gubernur Utama dan Wakil Gubernur Utama berwenang memberikan arahan umum kebijakan, pertimbangan, persetujuan dan veto terhadap rancangan Peraturan Daerah Istimewa yang diajukan DPRD dan Gubernur dan/ atau Peraturan Daerah yang berlaku."
Dalam naskah akademik RUU tentang Keistimewaan DIY tergambar bahwa hak veto yang nantinya akan diberikan untuk Sultan dan Paku Alam merupakan "senjata” mereka dalam melaksanakan fungsi kontrol terhadap kebijakan dalam urusan pertanahan untuk rakyat Yogyakarta. Namun pemberian hak veto tersebut belum memecahkan rumitnya urusan pertanahan di Yogyakarta. Kerumitan yang nantinya timbul antara lain pada mekanisme pengaturan hak veto tersebut nantinya ketika akan di implementasikan, hak veto yang diberikan kepada Sultan dan Pakualam ketika nanti Kepala Daerah dan Wakil Kepala Daerah bukan Sultan atau Paku Alam yang sedang jumeneng lebih terkait pada mekanisme pengaturan, bukan tentang hak milik atas tanah. Hak veto yang diberikan lebih kepada sebuah kontrol terhadap langkah-langkah pemerintah yang dipandang bertentangan dengan atau menyimpang dari norma-norma dasar yang dikenal dan dianut oleh masyarakat Yogyakarta.

Harus diberikan batasan-batasan yang jelaspengunaan hakvetotersebut. Bagaimana kekuatan veto yang dimiliki oleh Sultan dan Paku Alam juga harus dipertegas. Samakah dengan kekuatan hak veto yang dimiliki oleh lima anggota tetap Dewan Keamanan PBB yang memiliki efek mempengaruhi bahkan merubah setiap resolusi Dewan Keamanan. Apakah Sultan dan Paku Alam boleh menggunakan hak veto dengan bebas. Sebab jika digunakan dengan bebas maka dapat menimbulkan kesewenang-wenangan. 


\section{$\mathrm{R}^{\text {juenal }}$ ECHSVINDING}

Dan ketika dibatasi maka alasanalasan apa saja yang dapat menjadi dasar digunakannya hak veto oleh Sultan. Selain itu apakah hak veto Sultan bersifat mutlak, artinya langsung menggugurkan rancangan peraturan daerah yang diajukan baik oleh pemerintah daerah maupun DPRD. Sebab jika hak veto tersebut bersifat mutlak maka bagaimana dengan nasib rancangan perda yang telah disusun apakah masih boleh diajukan kembali. Mekanisme tersebut harus dipikirkan dengan matang agar nantinya tidak menimbulkan masalah baru.

Ketika nantinya Gubernur dan Wakil Gubernur tidak dijabat oleh Sultan atau Paku Alam atau kerabat keraton sebagai akibat dari sistem pemilihan kepala daerah langsung. Dikhawatirkan kepala daerah yang terpilih nantinya kurang memahami secara arif dan benar bagaimana relasi masyarakat dengan tanah. Kekhawatiran bahwa akan muncul sifat otoriter yang dengan semena-mena menghapuskan dan/ atau mengambilalih hak-hak rakyat yang telah diberikan oleh Sultan dan Paku Alam.

Kekhawatiran terbesar adalah terjadi tindakan melepaskan dan/atau melakukan tukar-menukar aset tanah wewengkon Kasultanan dan Pura Pakualaman kepada investor baik domestik apalagi investor asing melalui produk hukum Peraturan Gubernur. Sehingga cepat atau lambat akan terjadi hal-hal yang di khawatirkan oleh pihak Kasultanan dan Pura Paku Alaman bahwa wewengkon keraton nantinya hanya tinggal selebar terkembangnya payung (mung kari sak megaring songsong).

Kekhawatiran tersebut bukanlah sesuatu yang berlebihan. Sebab sebagaimana telah terurai di atas dalam sejarah pengaturan tanah di Kasultanan Yogyakarta dan Pura Pakualaman, kewenangan Sultan dan Paku Alamtidakhanyaterbatas dalamkeikutsertaan atau hanya merupakan hak konstitusional penguasa untuk mencegah, menyatakan, menolak, atau membatalkan keputusan saja semacam hak veto. Namun juga termasuk memiliki tanah dan mendistribusikan kepada rakyatnya untuk kesejahteraan rakyatnya.

Menghilangkan suatu tradisi yang telah lama hidup dalam suatu masyarakat terlebih tidak pernah ada konflik di dalamnya yang menyebabkan perpecahan tentunya tidak mudah. Masyarakat sudah terlanjur nyaman dengan kondisi tersebut apalagi ketika dirasa tidak merugikan diri mereka. Namun dualisme pengaturan urusan pertanahan yang terjadi di Yogyakarta tentunya menimbulkan ketidakpastian hukum, yang sebenarnya merugikan masyarakat sendiri terutama mereka yang telah turun temurun mendapatkan kepercayaan menggunakan tanah-tanah Kasultanan dan Pura Pakulaman. Secara hukum nasional status mereka terhadap tanah tersebut menjadi tidak jelas karena tidak tercatat secara nasional.

Selain Pasal 7 yang mengatur urusan kewenangan dibidang pertanahan. Dalam RUU Keistimewaan DIY urusan pertanahan diatur juga dalam Pasal 10 : 
Gubernur Utama dan Wakil Gubernur Utama berwenang:

a. Memberikan arah umum kebijakan dalam penetapan kelembagaan Pemerintah Daerah Provinsi, kebudayaan, pertanahan, penataan ruang, dan penganggaran;

b. Memberikan persetujuan terhadap rancangan Perdais yang telah disetujui bersama oleh DPRD Provinsi Daerah Istimewa Yogyakarta dan Gubernur;

c. Memberikan saran dan pertimbangan terhadap rencana perjanjian kerjasama yang dibuat oleh Pemerintah Daerah Provinsi dengan pihak ketiga yang membebani masyarakat.

Pasal yang secara utuh mengatur masalah pertanahan diatur pada Bagian Ketiga tentang Pertanahan dalam Pasal 26 :

1) Dalam rangka penyelenggaraan kewenangan pertanahan dan penataan ruang sebagaimana dimaksud dalam Pasal 7 ayat (2) huruf d, Kasultanan dan Pakualaman ditetapkan sebagai Badan Hukum.

2) Sebagai Badan Hukum, Kasultanan mempunyai hak milik atas Sultanaat Grond.

3) Sebagai Badan Hukum, Pakualaman mempunyai hak milik atas Pakualamanaat Grond.

4) Sebagai Badan Hukum, Kasultanan dan Pakualaman merupakan subyek hukum yang berwenang mengelola dan memanfaatkan Sultanaat Grond dan Pakualamanaat Grond dengan sebesar- besarnyaditujukanuntukpengembangan kebudayaan, kepentingan sosial, dan kesejahteraan masyarakat.

5) Ketentuan lebih lanjut tentang Badan Hukum diatur dengan Peraturan Pemerintah.

6) Tata guna, pemanfaatan, dan pengelolaan Sultanaat Grond dan Pakualamanaat Grond serta penataan ruang Provinsi Daerah Istimewa Yogyakarta diatur lebih lanjut dengan Perdais.

Setelah semua aturan terkait kewenangan di bidang pertanahan, pasal selanjutnya mengatur mengenai tugas atau kewajiban yang dibebankan kepada Sultan dan Paku Alam untuk melakukan konsolidasi dan klasifikasi pertanahan sebagaimana diatur dalam Pasal 35 huruf (c dan d):

1) Sri Sultan Hamengku Buwono $X$ dan Sri Paku Alam IX masing-masing dalam kedudukannya sebagai Sri Sultan dan Sri Paku Alam memiliki tugas:

- melakukan konsolidasidan klasifikasi Sultanaat Grond dan Pakualamanaat Grond;

- mendaftarkan hasil klasifikasi dan konsolidasi tanah sebagaimana dimaksud pada huruf c kepada Badan Pertanahan Nasional Republik Indonesia;

2) Sri Sultan Hamengku Buwono $X$ dan Sri Paku Alam IX dalam kedudukannya sebagai Gubernur dan Wakil Gubernur Provinsi Daerah Istimewa Yogyakarta sebagaimana dimaksud dalam Pasal 34 huruf (e) mempunyai tugas menyiapkan 


\section{$\mathrm{R}^{\text {juenal }}$ ECHSVINDING}

kerangka umum kebijakan pengelolaan dan pemanfaatan Sultanaat Grond dan Pakualamanaat Grond, serta penataan ruang Provinsi Daerah Istimewa Yogyakarta;

Berbagai pasal yang terdapat dalam RUU Keistimewaan DIY masih belum memberikan kepastian hukum. Salah satunya sebagaimana telah diuraikan diatas, terkait hak veto dalam rangka pelaksanaan kewenangan Sultan dan Paku Alam.

Hal lainyangterkesan belum memberikan kepastian hukum adalah kedudukan Sultan dan Paku Alam dalam urusan pertanahan, juga tidak ditegaskan urusan pertanahan yang mana yang menjadi keistimewaan Sultan dan Paku Alam. Sebab seperti telah diurai diatas, bahwa tanah di Yogyakarta bermacam-macam jenis dan golongannya. Sehingga menimbulkan pertanyaan apakah pertanahan yang diatur terutama dalam Pasal 10 apakah sama dengan Pasal 7 ataukah dengan pertanahan sebagaimana diatur dalam Pasal 26 RUU Keistimewaan ini.

Pertanahan dalam Pasal 7 dan Pasal 10 tidak dijelaskan dengan lebih rinci, berbeda dengan pertanahan yang ada dalam Pasal 26 di sebutkan dengan lebih rinci yaitu Sultanaat Ground dan Paku Alamanaat Ground. Hal ini dikhawatirkan akan menimbulkan penafsiran yang berbeda-beda tentang pertanahan tersebut. Kondisi ini akan menyulitkan terkait dengan dengan pelaksanaan teknisnya nanti dilapangan, sebab nantinya ada perbedaan antara Sultanaat Ground, Pakualamanaat Ground, tanah milik Pemerintah Daerah DIY dan milik rakyat DIY, dan juga tanah milik masing-masing ahli waris dari Sultan dan Pakualaman.

Selain status pertanahan dalam RUU ini juga belum dipaparkan secara rinci mengenai hak atas tanahnya. Dalam hal ini termasuk juga kedudukan Sultan sebagai pihak yang mempunyai hak istimewa dalam bidang pertanahan di Yogyakarta. Diperlukan suatu rumusan yang komprehensif tentang pengaturan hak atas tanah yang dimiliki oleh Sultan. Harus dibedakan dengan sedemikian rupa mana hak-hak yang seharusnya menjadi hak pemerintah, dan mana yang seharusnya menjadi hak yang memang karena keistimewaan Yogyakarta menjadi hak dari Sultan dan Pakualam.

Dalam rangka memberikan kepastian hukum terhadap keraton telah banyak dilakukan berbagai macam diskusi maupun sarasehan. Salah satu bentuk pemberian hak atas tanah kepada Kasultanan dan Pakualaman ${ }^{19}$ :

- Hak Pengelolaan (HPL) bagi Kasultanan dan paku alaman.

HPL merupakan bentuk khusus dari Hak Menguasai Negara (HMN), sebab HPL mempunyai kewenangan yang bersifat publik disamping juga kewenangan yang

19 Nurhasan Ismail, Sistem Pertanahan di DIY dalam Kerangka keistimewaan, Makalah Seminar yang diselenggarakan PARWI FOUNDATION, 26 April 2003, Novotel, hal. 9. 
bersifat perdata terbatas. Dengan HPL, maka Kasultanan dan Pura Pakualaman dapat melakukan kewenangan antara lain :

1) Menyusun rencana peruntukan dan penggunaan tanah-tanah yang dimiliki untuk berbagai kepentingan dan kegiatan yang bersifat sosial, budaya dan ekonomi dengan tetap mengedepankan serta berpijak pada prinsip "Tahta untuk rakyat".

2) Menggunakan sendiri tanahtanah yang diperuntukkan bagi kepentingan yang terkait langsung dengan simbol-simbol dan eksistensi lembaga Kasultanan dan Pura Pakualaman.

3) Sedangkan untuk tanah-tanah yang saat ini digunakan oleh rakyat baik untuk tempat tinggal maupun untuk kegiatan usaha, sejalan dengan prinsip Tahta untuk Rakyat, maka pengurusannya tetap diserahkan kepada rakyat yang bersangkutan sesuai dengan rencana peruntukan dan penggunaan tanah sebagaimana telah disusun dalam perjanjian awal penggunaan tanah milik Kasultanan dan Pura pakualaman. Untuk kepastian hukumnya, terhadap tanah-tanah ini pihak kasultanan dan Pura Pakulaman dapat merekomendasikan kepada Badan Pertanahan Nasional (BPN) Propinsi Yogyakarta untuk memberikan Hak Guna Bangunan atau Hak Pakai kepada rakyat yang menguasainya, sehingga HPL-nya tidak hilang. Di sisi lain rakyat yang menguasai dan menggunakan tanah-tanah milik Kasultanan dan Pura Pakualaman juga semakin diperkuat status hak nya sehingga secara yuridis dan ekonomis lebih duntungkan.

Berdasarkan hukum yang berlaku, HPL hanya dapat diberikan kepada instansi pemerintah dan Badan Usaha Milik Negara/Daerah (BUMN/D) sehingga perlu penegasan dan penentuan sikap baik dari negara dan Pihak Kasultanan dan Pura Pakulaman, karena hingga saat ini status mereka belum jelas apakah merupakan badan hukum publik atau badan hukum privat.

- Pemberian Hak Milik (HM)

Hak milik adalah hak atas tanah yang hanya mengandung kewenangankewenangan yang bersifat keperdataan saja. Dengan HM pihak Kasultanan dan Pura Pakualaman masih dapat melaksanakan prinsip "Tahta Untuk Rakyat" melalui pemberian HGB atau Hak Pakai diatas tanah HM kepada warga masyarakat yang sudah menguasai dan menggunakan. HM hanya dapat diberikan kepada orang perseorangan yang berstatus Warga Negara Indonesia Tunggal, sehingga badan hukum baik privat maupun publik pada prinsipnya tidak dapat mempunyai HM, kecuali 


\section{$\mathrm{R}_{\mathrm{E}}^{\text {juknal }}$ HTSVINDING}

ditunjuk langsung oleh pemerintah. Sehingga Kasultanan dan Pura Pakualaman dimungkinkan menjadi badan hukum dengan HM, asalkan mereka membentuk badan hukum privat seperti Yayasan atau berdasarkan penetapan dari dengan Perda sebagai badan hukum publik.

Pengaturan status tanah mana pun yang nantinya diterapkan dan dipilih, diharapkan mampu memberikan kepastian hukum urusan pertanahan di Yogyakarta. Pengaturan tersebut penting dalam rangka penataan dan pengelolaan kepemilikan aset dan tanah Kasultanan dan Pakualaman.

Langkah yang tidak kalah penting adalah pendataan oleh Badan Pertanahan Nasional (BPN) mengenai tanah-tanah di Yogyakarta berdasarkan penggolongannya. Agar nantinya dalam RUU Keistimewaan DIY ini dapat dilampirkandatapertanahandiYogyakarta secara lebih terperinci antara Sultanaat Ground, Pakualamanaat Ground, tanah milik pemerintah DIY,tanah milik rakyat.

Menanggapi kekhawatiran masyarakat Yogyakarta dengan munculnya RUU Keistimewaan DIY yang ditakutkan akan mengganggu atau mengambil tanah milik Keraton yang telah lama mereka kelola, baik sebagai tempat tinggal, tanah garapan, untuk sekolahan, tempat ibadah dan lain sebagainya. Ada baiknya kekhawatiran tersebut dihilangkan, karena apabila digarap dan dirumuskan dengan serius, RUU Keistimewaan DIY ini akan memberikan kepastian hukum dalam urusan pertanahan.

Manfaat langsung yang dirasakan oleh rakyat Yogyakarta terhadap tanah yang mereka tempati, walaupun berstatus magersari namun tercatat dalam sistem hukum nasional. Kondisi ini tentunya menguntungan juga bagi rakyat Yogyakarta yang hidup dalam koridor hukum NKRI.

\section{F. Penutup}

\section{1) Kesimpulan}

a. Sejarah penguasaan dan pemilikan tanah oleh raja atau Sultan Yogyakarta dan Paku alam merupakan pelaksanaan kesepakatan dari perjanjian Giyanti. Perjanjian yang dilaksanakan di daerah Giyanti pada tanggal 13 Februari 1755 membagi Kerajaan Mataram menjadi dua, yaitu Kasunanan Surakarta (Susuhunan) dan Kasultanan Ngayogyakarta Hadiningrat (Kasultanan). Pada masa kekuasaan Inggris, oleh Letnan Gubernur Thomas Stamford Raffles, wilayah Kasultanan Yogyakarta disempitkan lagi pada tahun 1813 menjadi wilayah Kasultanan dan wilayah Pakualaman. Hasil perjanjian Giyanti menyatakan bahwa Sultan Hamengku Buwono mempunyai hak milik (domein) atas tanah di wilayah barat Kerajaan Mataram dan hal ini tetap harus hidup dalam 
kesadaran hukum masyarakat. Masih berlangsungnya pengaturan oleh Sultan dan Pakualam menimbulkan kesan adanya dualisme hukum pertanahan di Yogyakarta. Namun hal tersebut merupakan konsekuensi dari keistimewaan yang dimiliki oleh Yogyakarta dibandingkan dengan daerah lain di Indonesia. Keistimewaan yang dimiliki oleh Yogyakarta berawal dari keluarnya Amanat Sri Paduka Sultan Hamengku Buwono IX dan Sri Paduka Paku Alam VIII pada tanggal 5 September 1945 yang menyatakan bahwa Kasultanan Ngayogyakarta Hadiningrat dan Kadipaten Pakualaman adalah daerah istimewa dan merupakan bagian dari wilayah Republik Indonesia. Dalam amanat Penggabungan diri tersebut Sultan dan Paku Alam menyertakan kewenangan untuk menangani segala urusan pemerintahan di daerahnya.

b. Yogyakarta mempunyai sistem pengelolaan tanah yang khusus. Sebagian diatur dengan UUPA atau mengikuti hukum pertanahan nasional yang berlaku dan beberapa wilayah masih diatur oleh Rijksblad Kasultanan dan Rijksblad Paku Alaman.Kondisi ini sebagai akibat dari pemberian status daerah istimewadiYogyakarta. Dimanasalah satu bentuk keistimewaan adalah hak untuk mengatur dan mengurus pertanahan secara mandiri. Urusan pertanahan pada masa Kasultanan diatur sendiri oleh Sultan dibantu abdi dalemnya yang disebut Paniti Kismo. Berdasarkan Risjkblad yang dikeluarkan oleh lembaga Kasultanan dan Paku Alaman Sultan dan Pakualam berkuasa penuh dan mutlak atas tanah yang ada di wilayahnya. Kasultanan mempunyai kewenangan untuk menyusun rencana peruntukan dan penggunaan tanah-tanah yang dipunyaiuntukberbagaikepentingan dan kegiatan yang bersifat sosial, budaya dan ekonomi. Kasultanan dan Paku Alaman berwenang untuk menggunakan sendiri tanahtanah yang diperuntukkan bagi kepentingan mereka terutama yang terkait langsung dengan simbol dan eksistensinya. Seiring perjalanan waktu ternyata keistimewaan Yogyakarta semakin kabur karena tidak sinergis dengan hukum nasional yang ada. Kebutuhan akan adanya undang-undang baru yang melindungi dan mengatur keistimewaan Yogyakarta mutlak dibutuhkan. Urusan pertanahan dalam draft RUU Keistimewaan DIY diatur dalam Pasal 7 ayat (2) d "Kewenangan dalam urusan istimewa sebagaimana dimaksud pada ayat (1) mencakup pertanahan 


\section{$\mathrm{R}_{\mathrm{EC}}^{\text {dunal HTSVINDING }}$}

dan penataan ruang". Dalam penjelasan Pasal itu disebutkan bahwa kewenangan dalam urusan pertanahan dan penataan ruang meliputi kewenangan untuk mengatur dan mengurus kepemilikan, penguasaan dan pengelolaan Sultanaat Grond dan Pakualamanaat Grond. Khusus di bidang pertanahan, Sultan dan Pakualam sebagai Gubernur utama dan Wakil Gubernur utama berwenang memberikan arahan umum kebijakan, pertimbangan, persetujuan dan veto terhadap rancangan Peraturan Daerah Istimewa yang diajukan DPRD dan Gubernur dan/atau Peraturan Daerah yang berlaku.

\section{2) Saran}

Perlu kajian lebih mendalam serta sosialisasi yang lebih luas atas RUU Keistimewaan DIY, terutama terkait pengaturan pertanahan agar tidak menimbulkan masalah atau polemik baru, khususnya dalam urusan pertanahan harus diatur dengan cermat sehingga nantinya tidak memunculkan masalah baru yang berpotensi menimbulkan perpecahan di kalangan internal masyarakat yogyakarta serta selaras dengan sistem hukum nasional. 


\section{R E⿱unenal HTSVINDING}

\section{DAFTAR PUSTAKA}

Harsono, Boedi, Undang-Undang Pokok Agraria, Sejarah Penyusunan Isi dan Pelaksanaannya,

(Djakarta: Djambatan, 1968).

Rajagukguk, Erman, Pemahaman Rakyat tentang Hak atas Tanah, Prisma, Jakarta,1979.

Notoyudo, KPH dalam Umar Kusumoharyono, Eksistensi Tanah Kasultanan (Sultan Ground)

Yogyakarta setelah berlakunya UU No. 5 / 1960, Yustisia Edisi Nomor 68 Mei - Agustus 2006.

Sumardjono, Maria SW, kebijakan Pertanahan Antara Regulasi dan Implementasi, Kompas, Jakarta, 2001.

Moedjanto, G., Kasultanan Yogyakarta dan Kadipaten Pakualaman, (Yogyakarta: Kanisius, 1994).

Rahardjo, Satjipto, Ilmu Hukum, (Bandung: Alumni, 1982).

Soemardjan, Selo, Perubahan Sosial di Yogyakarta, (Yogyakarta: Gadjah Mada University Press, 1981).

Soedargo, Hukum Agraria dalam Era Pembangunan, Prisma, nomor 6, tahun 1973.

Soekanto,Suryono \& Sri Mamudji, Penelitian Hukum Normatif, Suatu Tinjauan Singkat, (Jakarta: Raja Grafindo Persada, 2003).

Haar, Ter, Asas-asas Dan Susunan Hukum Adat, Terjemahan oleh K. ng. Soebakti Poesponot, (Jakarta: Pradnya Paramita, 1985).

Utomo, Tri Widodo, Hukum Pertanahan Dalam Perspektif Otonomi Daerah, (Yogyakarta: Navila, 1992).

Tauchid, Mochammad, Masalah Agraria Sebagai Masalah Penghidupan dan Kemakmuran Rakyat Indonesia, Bagian Pertama, (Djakarta: Tjakrawala, 1952).

Ismail, Nurhasan, Sistem Pertanahan di DIY dalam Kerangka keistimewaan, Makalah Seminar yang diselenggarakan oleh PARWI FOUNDATION, 26 April 2003, Novotel.

Risalah Rapat Panitia Kerja Komisi II DPR RI, Tentang Rancangan Undang-Undang Tentang Keistimewaan Propinsi Daerah Istimewa Yogyakarta, Senin,10 Oktober 2011.

http://pusatbahasa.kemdiknas.go.id/kbbi/

http://www.kotajogja.com/

http://triwidodowutomo.blogspot.com/2010/05/hukum-pertanahan-di-yogyakarta-sebelum. html. 